\title{
Mateera, watermelon (Citrullus lanatus) germplasm utilization for improving fruit quality and marketable harvest under hot arid climate of India: approaches and out-put
}

\section{DK Samadia \& SM Haldhar}

Journal of Agriculture and Ecology

ISSN: 2456-9410

Volume: 10

Journal of Agriculture and Ecology (2020) 10: 1-21 http://doi.org/10.53911/JAE.2020.10201

बि एवं शुष्क पारिस्थितिकी अनुसंधान सोसाइटी Society for Agriculture and Arid Ecology Research Bikaner (Rajasthan) LNDIA-334006 Website: www. Saaer.org.in 


\title{
Mateera, watermelon (Citrullus lanatus) germplasm utilization for improving fruit quality and marketable harvest under hot arid climate of India: approaches and out-put
}

\author{
DK Samadia ${ }^{1} \square \&$ SM Haldhar ${ }^{1,2}$ \\ ${ }^{1}$ ICAR-Central Institute for Arid Horticulture, Beechwal, Bikaner-334006 \\ ${ }^{2}$ Present: Associate Professor, Entomology, College of Agriculture CAU, Imphal \\ $\square$ Corresponding author: DK Samadia, E-mail: samadiadk@yahoo.com
}

\section{Article Info}

Article history

Received: 22 September 2020

Accepted: 20 November 2020

Available online: 31 December 2020

Key Words: Citrullus, mateera, watermelon, tumba, tinda, drought tolerant germplasm, crop improvement, hot arid environment.

\begin{abstract}
Cucurbits, a big group of vegetable cultivated extensively in India. It consist wide-range of crops used in culinary, salad, dessert, pickling and processing. Indigenous cucurbits both fresh and dehydrated form ensuring nutritious food to inhabitants of tribal and desert areas. Kachri, kaakdia, mateera, tinda and tumba is grown under rainfed situations and its cultivation is admired with the traditional farming in north-western parts of Rajasthan. Mateera is under-utilized, drought tolerant and native form of watermelon. Its nutrition rich tender and ripen fruits and seed-kernel liked by desert dwellers and sold at high premium. For developing drought and heat tolerant genotypes in mateera, ICAR-CIAH initiated first-time intensive research and wide range of Citrullus germplasm collected, conserved and utilized in crop improvement work from 1994 to 2012. In past, absence of standard varieties in drought tolerant mateera, the arid zone farmers obliged to use heterozygous seed collected from fruits (based on taste) of own fields. This obviously results poor and no-insured quality. On evaluation of the Citrullus germplasm (254 entries) at Bikaner, watermelon genotypes failed to express their potentialities under high temperature and rainfed conditions. Therefore, use of indigenous and generated variability, and promotion of varieties from native germplasm is found to be beneficial. Mateera line AHW-18, AHW-19, AHW-65, AHW-108, AHW-140, AHWRSS-1 and AHW-BSM-1 are promising for use in breeding or trait-specific selections. The developed mateera varieties i.e. AHW-19 and Thar Manak are early in harvesting, producing better quality fruits and multiple-use, and recommended for cultivation under resource constraints hot arid environment.
\end{abstract}

Copyright (C2020 Samadia \& Haldhar, This is an open access article published under the terms of the Creative Commons Attribution License, which permits unrestricted use, distribution, and reproduction in any medium, provided the original work is properly cited.

Preferred citation: Samadia DK \& Haldhar SM. 2020. Mateera, watermelon (Citrullus lanatus) germplasm utilization for improving fruit quality and marketable harvest under hot arid climate of India: approaches and out-put. Journal of Agriculture and Ecology, 10: 1-21; http://doi.org/10.53911/JAE.2020.10201. 


\section{Introduction}

The Indian sub-continent is rich in cucurbitaceous crop-plants diversity. In vegetable group, both annual and perennial cucurbits play significant role and widely used for cooking, salad, dessert and processing. The arid and semi-arid region of north-western India is endowed with wide-range of genetic variability in particular to Citrullus and Cucumis having multiple-use and drought tolerant attributes. Indigenous cucurbits viz., kachri, kaakdia, mateera, tinda and tumba are component crops of traditional farming and playing vital role in providing nutritious food and income to inhabitants of desert ecosystem (Pareek \& Samadia 2002; Pareek et al. 1999). Among Citrullus, mateera is native form of watermelon (C. lanatus) and is much useful to farmers for getting benefits from ripen fruits, loiya, seed, rainfed, organic, lowinput and less-water requiring cropcommodity in the hot arid area of Rajasthan. Non-edible fruits bearing and perennial species, tumba or indrayan is bitter melon $(C$. colocynthis) and ripen fruits used for pickle making, medicine, seed-oil and bio-fuel. Third-one is seasonal and popular vegetable of dry-land i.e. tinda or round melon (Praecitrullus fistulosus; syn. Citrullus vulgaris var. fistulosus) and widely grown for its immature and dehydrated fruits (phophalia) for culinary. These rescue cucurbits predominantly grown on sand-dune landscape and desert sandy soil, rainfed and mixed-crop with bajra and legume (cluster bean, moth bean and cowpea) during the kharif season (Samadia \& Pareek 1996; Haldhar et al. 2015).

Non-availability of trait-specific and requisite genotype suited to abiotic stressed production sites of Indian arid zone is prime limiting factor in promoting native cucurbits. Therefore, long-term research work-plan was made at ICAR-CIAH, Bikaner with the objective to improve drought hardy Citrullus species variability for quality fruit yield under dry-land climate of Rajasthan. Owing to low moisture and heat stresses adaptability and also high fruit bearing capacity of native Citrullus, a wide-range of germplasm was assembled through explorations and augmentation (Samadia 2007). To collect the regional cucurbits genetic diversity, intensive surveys were conducted from 1994 to 2003, and evaluated and categorized for use in selection and hybridization breeding. In addition, a large number of generated progenies from germplasm and breeding material developed through identified parentage combinations were studied over the seasons and years to conclude the results of strategic research programme of varietal development, and elaborated in this paper.

\section{Materials and Methods}

Physiography and agro-climate: In India, Rajasthan $\left(23^{\circ} 3^{\prime}-30^{0} 12^{\prime} \mathrm{N}\right.$ and $69^{\circ} 3^{\prime}-$ $\left.78^{0} 17^{\prime} \mathrm{E}\right)$ is geographically big state and 40 $\%$ area is hot arid (19.6 million hectare) and remaining is semi-arid and dry-land climate. Here, annual rainfall varies from 150 to 550 $\mathrm{mm}$ and is erratic. Out of 9-21 mean rainydays/annum, much of rain often comes in a few (1-5) heavy events during monsoon season (June-September) and is un-certain. In kharif, day-time high temperature range 35$42^{\circ} \mathrm{C}$ and prolonged drought spells of $15-35$ days in-together sandy soils creates an environment where very few native crops can 
survive and viable under rainfed situations. The collected mateera germplasm, varieties and breeding material was evaluated at experimental farm of CIAH, Beechwal, Bikaner $\left(28^{0} 6^{\prime} \mathrm{N}\right.$ latitude and $73^{\circ} 2^{\prime} \mathrm{E}$ longitudes and altitude $223 \mathrm{~m}$ ) and this area is hyper-arid zone. In hot arid areas, winter is dry and minimum temperature fluctuates (4$10^{0} \mathrm{C}$ ) in December-January and some-times it prolonged to February. Most of years, low temperature dips-down below freezing ( -1 to $-6^{0} \mathrm{C}$ ) and frost is very common. Here, winter temperature variability determinates sowingtime and cropping period. In north-western part of the state, March-October months are hot, dry and sunny with continuity of high temperatures around $38^{0} \mathrm{C}$ for prolonged period and results to excessive evapotranspiration from crop-plants and soilsurface. In summer, maximum temperature in May-June is above $40^{\circ} \mathrm{C}$ in east to $42^{\circ} \mathrm{C}$ in the west zone. But it is very common to experiences extremes of temperature 42-47 and $45-50^{\circ} \mathrm{C}$ for the numbers of days (21-28 days), respectively and this period night temperature $\left(31-35^{\circ} \mathrm{C}\right)$ is also very high.

Sand-dune or desert-field soil is coarse texture, poor in organic matter, nutrients and water holding capacity. Sand, fertile top-soil and fine particles continuing blow-away due to strong wind and thus affecting crop production potential. The crop-plants get damaged through sand blasting on seedlings, leaves, stem, buds, flowers and tender fruits during heat-waves and dusty wind-storms (LOO and ANDHI). The young seedlings buried under sand and vine-plant disturbed badly. During peak summer, adversity of heat stress is very high and vine growth and produce quality sun-burns, and some-times plants dried due to heat-strokes. To assess the crop-genotypes, experiments were conducted over the seasons and year with normal sowing $i$. e. on-set of monsoon rains in July month and mid-February with limited irrigations. Germplasm collection and augmentation: Realizing the potentials of regional diversity and mateera cultivation in dry-lands of northwestern parts of India, intensive surveys and explorations were organized in targeted variability pockets of arid, semi-arid and tribal areas of Rajasthan from 1994 and 2003 by CIAH, Bikaner. In addition, collaborative explorations were also made under the mission-mode of institute and NATP on plant bio-diversity programme with NBPGR (RS) Jodhpur for collection of dessert and nondessert forms of Citrullus and Cucumis germplasm in Rajasthan. Maximum variability and native land-races of mateera, tumba and tinda was collected from north-western districts (Bikaner, Churu, Nagour, Jodhpur, Barmer, Jaisalmer, Pali and Hanumangarh) with desert ecology, rainfed and mixed cropping during the kharif.

Whereas, watermelon germplasm (28 entries) was explored from Sikar, Jaipur, Tonk, Ajmer, Kota, Chittorgarh, Udaipur, Sirohi and adjoining districts with the semiarid climate and summer season cultivation. In addition, introduced and national watermelon genotypes (11 entries) were assembled from NBPGR, New Delhi, RARI, Durgapura (Jaipur), IIHR, Bengaluru and AICRP (vegetable crops) IIVR, Varanasi. In this way, a rich Citrullus diversity was collected through surveys and sampled from wide-range of locations having variable climate, soil, 
topography and production systems (rainfed, irrigated and river-bed). Open-pollinated fruit I seed samples were collected, biased or randomly and passport information was compiled on area, growth, fruits, variability pattern and cultivation practices at the production sites. Germplasm evaluation and utilization: Over the years collected Citrullus lanatus diversity either through surveys and explorations or assembled from other organizations at CIAH Bikaner were evaluated and characterized systematically and it was in phase-manner. Minimal descriptor with 35 attributes was used for vegetative growth, flowering and fruiting behaviour, maturity, fruit yield, quality and seed characters studies for all the material under evaluation. Both mateera and watermelon germplasm were categorized based on prioritized traits such as earliness, number of fruits, fruit quality and marketable yield under high temperature and abiotic stressed conditions of hot arid environment.

The improved watermelon varieties, hybrids, purified mateera material and developed lines were evaluated over the seasons and assessed to understand their potentialities under arid climate and also suitability for two season cultivation. Therefore, each germplasm or breeding material was studied at least four times as rainy and summer and rainfed and irrigated situations. For evaluation of each germplasm or breeding line, single-row of 25 metre length was kept standard throughout the experimental trials and 50 plants/genotype/row maintained. With the starts of flowering, twelve plants were tagged in each genotype and four groups were made for recording observations. Thus, collected Citrullus accessions (mateera-178, watermelon-39, tinda-32 and tumba-5) were evaluated in phase manner as well varying environments. A wide-range of data generated for mateera and watermelon germplasm and it was with seasons and production situations of 1995-1999 and 2000-2003 at CIAH, Bikaner. After evaluation, data were compiled to assess extent of genetic variability in germplasm, and genotypes short-listed based on performance and prioritized traits. Means of two season data of short-listed and selected genotypes were used for assessment of genetic variability components and means of four season crop data analyzed for comparative study. For purification of native mateera, promising germplasm lines were identified based on fruit quality trait and performance over the season. After purification, mateera selections were compared with standard watermelon varieties for fruit quality and yield component. Simultaneously, breeding for improvement of drought tolerant mateera through hybridization was initiated with the objectives to improve adaptive selections for acceptable flesh quality, higher sweetness and cultivation under water stress and high temperature conditions.

Here, the mateera selections (AHW18, AHW-19 and AHW-65) and watermelon varieties (Sugar Baby, Durgapura Meetha, Charleston Local and Mahobobi) were selected for hybridization breeding (single and diallel). The developed $\mathrm{F}_{1}, \mathrm{~F}_{2}, \mathrm{BC}_{1}, \mathrm{BC}_{2}$ and parents and bi-parental material were studied for their performance as rainy and summer season crop during 1999-2003. Promising segregates selected in $\mathrm{F}_{2}$ generation and breeding work advanced and emphasis was 
given through individual plant selection based on fruit flesh quality traits and adaptability under dry-land climate. From 2004-2010, most promising lines, selections and varieties of mateera and watermelon were evaluated with varying season and situations. Since, fruit flesh quality, cracking-free, marketable yield and tolerant to prevailing climatic conditions of arid region were prioritized components for mateera, therefore, long-term data were assessed in various formats to conclude the research work.

\section{Results and Discussions}

Scanty rains, extremes of high and low temperatures in-together associated abiotic stresses in hot arid and semi-arid areas of north-western India limiting crop-genotypes choice and produce quality (Samadia 2016). Here, vegetable intensification with adaptive and native crop-plant species is in-general found to be the most appropriate and stable with dry-land climate. Genetic diversity has vital role in making rapid crop improvement, and utilizing available variability we can develop genotypes with greater economic values and cultivation under a set of environmental conditions. Indian subcontinent is primary and secondary or an area of regional diversity for a large number of vegetable significant crop-plants. The drylands of north-western parts of country is also possesses good genetic diversity in most of cucurbits (Samadia 2018). Based on survey studies, it is come-up that the types of vegetable crop-plants found growing in arid and semi-arid area are distinctly different presumably due to the eco-adaptations and climatic variability. The north-western arid zone of Rajasthan grows some typical cucurbits and less-known vegetable significant crop-plants. The Aravalli range separates desert eco-system of the west zone from the eastern semi-arid zone, and here diverse vegetables are in traditional cropping. Under arid climate, rich genetic variability do exists in Citrullus and Cucumis group. In dry-lands, collection of native land-races, germplasm and varieties and their evaluation contributed maximum in vegetable diversification and production. Thus, collection, conservation and utilization would continue to be the best, dependable and desirable approach for crop improvement under abiotic stressed conditions of Rajasthan (Samadia 2007; Samadia \& Haldhar 2017; Haldhar et al. 2016).

Table1. Agro-morphological variations for important characters in evaluated mateera germplasm

\begin{tabular}{l}
\hline Character \\
\hline Vine length $(\mathrm{m})$ \\
Number of branches/plant \\
Days to opening of first male flower (DAS) \\
Days to opening of first female flower (DAS) \\
Node number to appearance of first female fl \\
Number of fruits-set/plant \\
Days to first harvesting of ripen fruits (DAS) \\
Number of marketable fruits/plant \\
Fruit length $(\mathrm{cm})$ \\
Fruit girth $(\mathrm{cm})$
\end{tabular}

\section{Range}

$2.21-6.50$

$3.12-6.45$

$24.5-45.2$

$40.2-55.5$

$5.4-18.5$

$3.5-20.8$

$72.5-110.5$

$0.85-7.45$

$10.32-40.50$

$25.91-73.54$ 
Fruit weight $(\mathrm{kg})$

Edible flesh thickness $(\mathrm{cm})$

Non-edible flesh thickness $(\mathrm{cm})$

Number of seeds/fruit

TSS $\left({ }^{0}\right.$ Brix $)$

Fruit shape

Fruit rind colour

Flesh colour and firmness
$0.50-8.55$

$9.85-18.55$

$1.25-3.15$

$280-840$

$2.12-10.5$

Round, oblong-round, oblong and long Green-dark green clear stripes, green and dark green not clear stripes or light green with narrow lines and netting Whitish, light pink, pink to reddish in colour and loose to medium in firmness Khaki, reddish, blackish, brownish, whitish and mottled
In vast-spread traditional farming systems of arid and semi-arid farm-lands, mixed cropping of pearl-millet (bajra), cluster bean, moth bean, moong bean or cowpea is dominating in millions of hectare. Here, indigenous cucurbits such as kachri, kaakdia, mateera, tinda and arya-kakri are the rescue and underutilized vegetable crops. In addition, native perennial tree-plants such as khejri, ker, lasora, kumat, jharber, bordi, khimp, phog, guarpatha and tumba have horticultural attraction, ensuring nutrition rich food produce and providing subsistence income under rainfed conditions to the desert dwellers. Likewise in semi-arid and tribal area, mixed cropping with maize, urd bean, moong bean, cowpea, cluster bean or pigeonpea is performed during the kharif and in which native forms / land-races of mat-kachar, phut, arya-kakri, wanga-kakri, chikan-kakri, kundru, kakoda, bhindi, bakala-phali, semphali, komba-phali and conch-phali are the supporting vegetables to the local inhabitants (Samadia \& Haldhar 2019; Choudhary et al. 2015). Hence, there are specific areas with multiple-stresses in the country like hot arid and unique forms in cucurbits are grown and on which not much research work is done for conserving diversity and its utilization. To fulfill vegetable and nutritious diet requirement, the best approach is to breed acceptable quality and high yielding varieties, and that should be superior to the existing ones and suited under extremes of climatic variability. By understanding the facts, systematic and intensive surveys in target variability pockets and crop-specific explorations in the arid, semi-arid and tribal dominating areas of Rajasthan and Gujarat were conducted for collection of wild, landraces and semi-cultivated germplasm of native cucurbits and un-exploited vegetable cropplants. A rich variability in mateera, watermelon, tinda and tumba was collected, evaluated and utilized over the years (1994 to 2012) as Citrullus genetic resource (254 entries) and presently 75 germplasm/ breeding material is being maintained at CIAH (Dwivedi et al. 2003; Samadia 2003). 


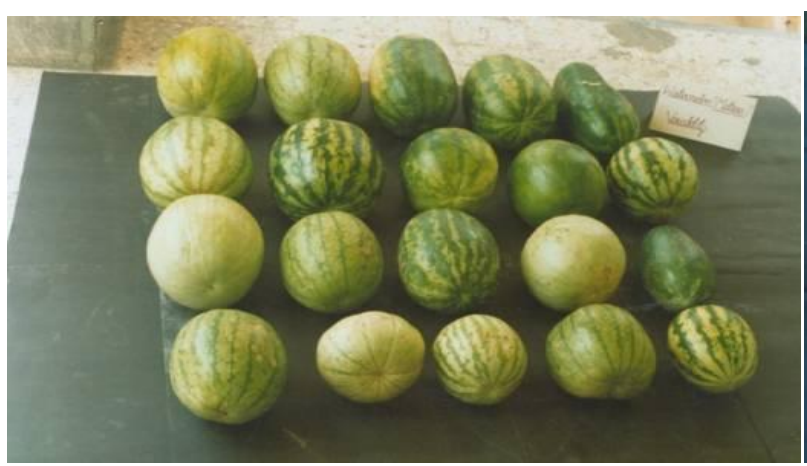

Fruit variability in indigenous mateera

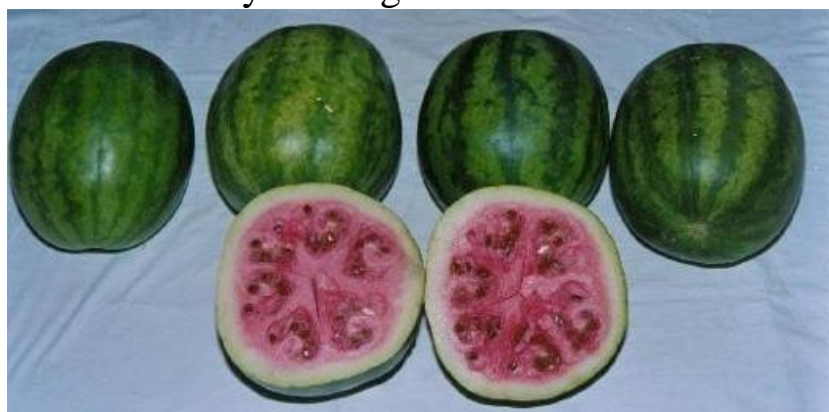

Fruits of mateera var. AHW-19

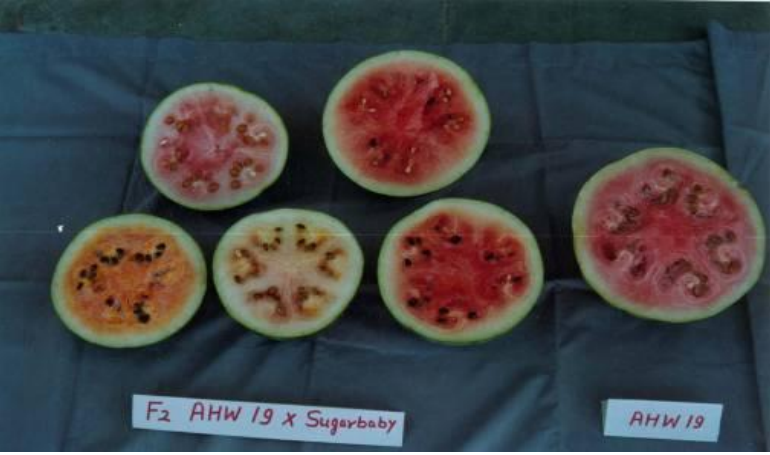

Flesh and quality variations in $\mathrm{F}_{2}$ generation

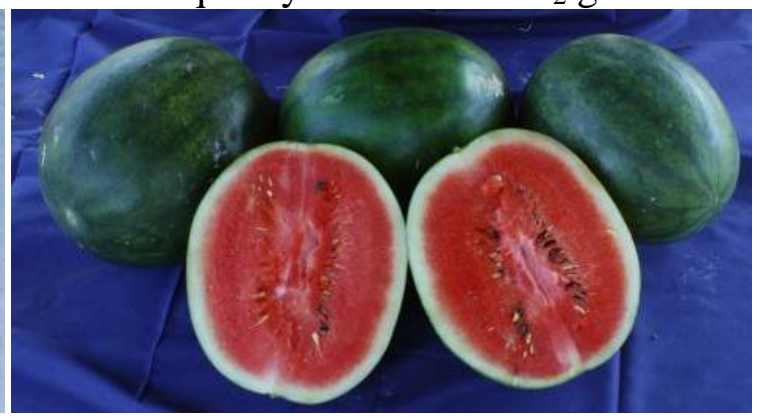

Fruit yielding mateera var. Thar Manak
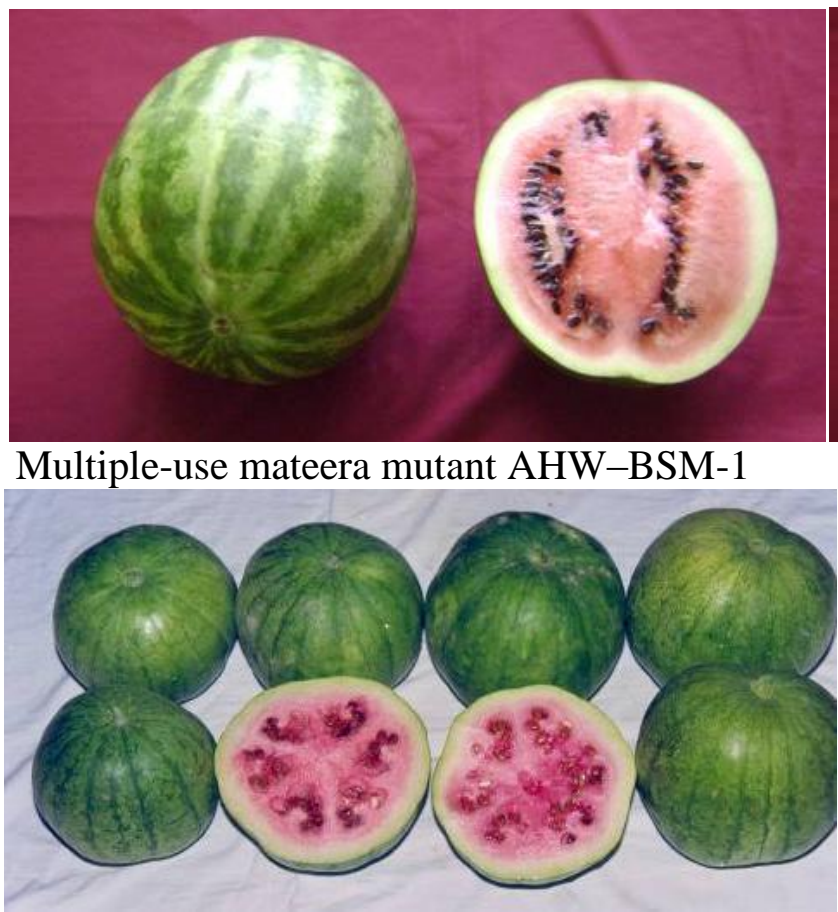

High seed yielding mateera AHW-RSS-1

Fruits of multiple-use mateera Var. AHW-65

High protein and edible oil rich mateera seeds

Plate 1. Genetic variabilty and utilization studies in drought tolerant mateera germplasm at CIAH 
Table 2. Growth, flowering, fruiting and quality characters of selected drought tolerant mateera genotypes (over the seasons)

\begin{tabular}{|c|c|c|c|c|c|c|c|c|c|c|c|c|c|c|}
\hline Genotypes & $\begin{array}{c}\text { Days to } \\
\text { first } \\
\text { female } \\
\text { flower } \\
\text { (DAS) }\end{array}$ & $\begin{array}{c}\text { Number } \\
\text { of fruit } \\
\text { set } \\
\text { / plant }\end{array}$ & $\begin{array}{c}\text { Days } \\
\text { to } \\
\text { first } \\
\text { harvest } \\
\text { (DAS) }\end{array}$ & $\begin{array}{c}\begin{array}{c}\text { Number } \\
\text { of }\end{array} \\
\text { marketable } \\
\text { fruits } \\
\text { / plant }\end{array}$ & $\begin{array}{c}\text { Fruit } \\
\text { weight } \\
\text { (kg) }\end{array}$ & $\begin{array}{c}\text { Fruit } \\
\text { length } \\
\text { (cm) }\end{array}$ & $\begin{array}{l}\text { Fruit } \\
\text { girth } \\
(\mathrm{cm})\end{array}$ & $\begin{array}{c}\text { Edible } \\
\text { flesh } \\
\text { thick- } \\
\text { ness } \\
\text { (cm) }\end{array}$ & $\begin{array}{c}\text { Non- } \\
\text { edible } \\
\text { flesh } \\
\text { thick- } \\
\text { ness } \\
\text { (cm) }\end{array}$ & $\begin{array}{c}\text { TSS } \\
\left({ }^{0} \text { Brix }\right)\end{array}$ & $\begin{array}{c}\text { Vine } \\
\text { length } \\
(\mathrm{m})\end{array}$ & $\begin{array}{c}\text { Number } \\
\text { of } \\
\text { branches } \\
\text { /plant }\end{array}$ & $\begin{array}{c}\text { Flesh } \\
\text { Colour* }\end{array}$ & $\begin{array}{c}\text { Flesh } \\
\text { grade* }\end{array}$ \\
\hline AHW- 01 & 49.78 & 6.86 & 93.35 & 2.63 & 5.23 & 40.83 & 61.68 & 16.32 & 2.36 & 7.22 & 4.20 & 6.46 & LP & B \\
\hline AHW-12 & 55.42 & 4.53 & 96.83 & 2.11 & 3.48 & 28.38 & 61.55 & 12.56 & 1.77 & 7.02 & 2.52 & 4.27 & LP & B \\
\hline AHW-16 & 53.42 & 7.76 & 90.54 & 3.70 & 4.23 & 28.72 & 58.42 & 14.38 & 2.05 & 7.51 & 2.55 & 4.52 & $\mathrm{P}$ & $\mathrm{A}$ \\
\hline AHW-18 & 48.46 & 8.83 & 82.37 & 4.84 & 4.16 & 30.52 & 61.65 & 14.51 & 1.82 & 8.04 & 4.52 & 6.24 & $\mathrm{DP}$ & $\mathrm{A}$ \\
\hline AHW- 19 & 47.87 & 8.60 & 80.50 & 4.59 & 3.93 & 35.65 & 59.58 & 12.46 & 1.60 & 8.44 & 3.01 & 5.55 & DP & $\mathrm{A}$ \\
\hline AHW-20 & 50.46 & 5.50 & 87.46 & 3.08 & 3.13 & 34.34 & 55.58 & 14.22 & 1.72 & 5.45 & 2.17 & 4.25 & LP & A \\
\hline AHW-65 & 44.15 & 9.91 & 78.05 & 5.26 & 2.83 & 28.97 & 55.55 & 13.23 & 1.73 & 8.22 & 2.56 & 5.61 & $\mathrm{P}$ & $\mathrm{A}$ \\
\hline AHW-73 & 45.16 & 7.63 & 88.44 & 4.57 & 3.75 & 31.77 & 55.44 & 10.64 & 2.24 & 6.41 & 3.56 & 5.46 & LP & B \\
\hline AHW-82 & 47.28 & 7.44 & 88.11 & 3.16 & 5.22 & 34.39 & 70.90 & 16.04 & 2.28 & 7.77 & 3.11 & 6.14 & $\mathrm{P}$ & B \\
\hline AHW-85 & 44.79 & 7.46 & 90.39 & 4.24 & 4.52 & 33.45 & 67.27 & 12.14 & 2.56 & 7.52 & 3.23 & 5.23 & LP & $\mathrm{B}$ \\
\hline AHW-108 & 46.47 & 8.36 & 86.96 & 4.12 & 3.48 & 28.71 & 55.38 & 12.81 & 1.63 & 8.06 & 4.13 & 6.19 & DP & A \\
\hline AHW-118 & 48.51 & 6.73 & 88.41 & 4.09 & 4.08 & 30.91 & 62.08 & 14.23 & 1.81 & 7.81 & 3.13 & 5.27 & DP & $\mathrm{A}$ \\
\hline AHW-120 & 48.91 & 6.60 & 88.12 & 4.44 & 4.23 & 34.09 & 64.24 & 15.18 & 1.80 & 7.63 & 3.24 & 6.20 & $\mathrm{P}$ & A \\
\hline AHW-123 & 49.36 & 6.77 & 86.55 & 4.07 & 4.84 & 33.40 & 68.00 & 12.44 & 2.83 & 6.08 & 2.84 & 6.35 & LP & B \\
\hline AHW-140 & 49.84 & 8.25 & 89.77 & 4.08 & 4.09 & 35.74 & 58.23 & 12.37 & 2.07 & 7.20 & 3.28 & 5.25 & LP & B \\
\hline Sugar Baby & 74.20 & 5.19 & 103.70 & 1.14 & 2.83 & 25.41 & 61.05 & 15.61 & 1.47 & 9.24 & 3.22 & 5.21 & $\mathrm{R}$ & AA \\
\hline $\begin{array}{l}\text { Durgapura } \\
\text { Meetha }\end{array}$ & 70.17 & 6.13 & 104.29 & 1.42 & 3.42 & 24.60 & 68.57 & 14.59 & 2.10 & 9.35 & 3.76 & 5.53 & $\mathrm{R}$ & $\mathrm{AA}$ \\
\hline Mean & 51.43 & 7.21 & 89.64 & 3.62 & 3.97 & 31.70 & 61.48 & 13.75 & 1.99 & 7.58 & 3.24 & 5.51 & - & - \\
\hline $\mathrm{CV}(\%)$ & 1.8 & 4.9 & 1.3 & 4.2 & 3.8 & 1.7 & 1.1 & 2.0 & 4.2 & 1.2 & 4.1 & 1.9 & - & - \\
\hline $\mathrm{CD}(5 \%)$ & 1.57 & 0.59 & 1.88 & 0.25 & 0.25 & 0.90 & 1.12 & 0.44 & 0.13 & 0.14 & 0.22 & 0.17 & - & - \\
\hline
\end{tabular}

* Light pink (LP), Pink (P), Dark pink (DP) and Red (R) colour; Very firm or solid (AA), Solid (A) and Semi-solid or loose (B) flesh. 
Journal of Agriculture and Ecology, 2020, Vol. 10, 1-21

http://saaer.org.in

Table 3. Mean performance of watermelon and mateera genotypes under hot arid conditions during 1996 and 1997 at CIAH, Bikaner

\begin{tabular}{|c|c|c|c|c|c|c|c|c|c|c|c|}
\hline Genotypes & $\begin{array}{c}\text { Days to } \\
\text { first } \\
\text { female } \\
\text { flower } \\
\text { (DAS) } \\
\end{array}$ & $\begin{array}{c}\text { Number of } \\
\text { fruit set } \\
\text { / plant }\end{array}$ & $\begin{array}{c}\text { Days } \\
\text { to } \\
\text { first } \\
\text { harvest } \\
\text { (DAS) } \\
\end{array}$ & $\begin{array}{c}\text { Number of } \\
\text { marketable } \\
\text { fruits } \\
\text { / plant }\end{array}$ & $\begin{array}{c}\text { Fruit } \\
\text { weight } \\
\text { (kg) }\end{array}$ & $\begin{array}{c}\text { TSS } \\
\stackrel{(0}{\left({ }^{\prime}\right.} \\
\text { Brix })\end{array}$ & $\begin{array}{c}\text { Vine } \\
\text { length } \\
(\mathrm{m})\end{array}$ & $\begin{array}{l}\text { Number of } \\
\text { branches } \\
\text { /plant }\end{array}$ & $\begin{array}{l}\text { Flesh } \\
\text { Colour }\end{array}$ & $\begin{array}{c}\text { Flesh } \\
\text { firmness }\end{array}$ & $\begin{array}{c}\text { Number of } \\
\text { cracked } \\
\text { fruits } \\
\text { /plant }\end{array}$ \\
\hline $\begin{array}{l}\text { Durgapura } \\
\text { Meetha }\end{array}$ & 53.78 & 5.83 & 99.15 & 2.06 & 3.98 & 9.03 & 3.90 & 5.23 & Red & Solid & 1.42 \\
\hline Sugar Baby & 57.40 & 5.60 & 98.61 & 1.50 & 2.53 & 9.46 & 3.05 & 4.20 & Red & Solid & 1.51 \\
\hline Arka Manik & 58.37 & 6.73 & 88.15 & 1.85 & 4.04 & 8.30 & 3.34 & 6.00 & $\begin{array}{l}\text { Dark } \\
\text { pink }\end{array}$ & $\begin{array}{l}\text { Semi- } \\
\text { solid }\end{array}$ & 1.33 \\
\hline Arka Jyoti & 51.68 & 8.53 & 86.38 & 1.86 & 4.12 & 8.96 & 3.07 & 5.97 & Red & Solid & 1.61 \\
\hline MHW-11 & 52.02 & 6.43 & 84.72 & 2.23 & 5.42 & 8.33 & 3.29 & 4.94 & $\begin{array}{l}\text { Dark } \\
\text { pink }\end{array}$ & Solid & 1.25 \\
\hline NHW-102 & 56.72 & 8.94 & 84.81 & 2.13 & 5.22 & 8.50 & 3.32 & 6.30 & $\begin{array}{l}\text { Dark } \\
\text { pink }\end{array}$ & Solid & 1.32 \\
\hline $\begin{array}{l}\text { Mateera } \\
\text { AHW-18 }\end{array}$ & 48.11 & 7.63 & 83.20 & 4.10 & 4.64 & 8.06 & 4.00 & 5.33 & Pink & $\begin{array}{l}\text { Semi- } \\
\text { solid }\end{array}$ & 0.00 \\
\hline $\begin{array}{l}\text { Mateera } \\
\text { AHW-19 }\end{array}$ & 44.08 & 8.86 & 79.91 & 4.30 & 3.93 & 8.33 & 3.35 & 5.46 & $\begin{array}{l}\text { Dark } \\
\text { pink }\end{array}$ & $\begin{array}{l}\text { Semi- } \\
\text { solid }\end{array}$ & 0.00 \\
\hline $\begin{array}{l}\text { Mateera } \\
\text { AHW-65 }\end{array}$ & 42.16 & 9.98 & 74.74 & 5.10 & 3.00 & 8.37 & 3.18 & 6.17 & Pink & $\begin{array}{l}\text { Semi- } \\
\text { solid }\end{array}$ & 0.00 \\
\hline Mean & 51.59 & 7.61 & 86.63 & 2.79 & 4.10 & 8.59 & 3.39 & 5.51 & -- & -- & -- \\
\hline CV (\%) & 1.9 & 5.2 & 1.5 & 6.4 & 3.9 & 2.3 & 5.5 & 3.2 & -- & -- & -- \\
\hline $\mathrm{CD}(5 \%)$ & 1.71 & 0.68 & 2.27 & 0.31 & 0.28 & 0.34 & 0.32 & 0.30 & -- & -- & -- \\
\hline
\end{tabular}


In Rajasthan, dessert and non-dessert forms of melon are cultivated extensively with varying seasons and production situations. Arid and semi-arid region of the north-western India is endowed with rich genetic diversity in most of melons and in particular to Citrullus group having drought tolerant and multipleuse attributes. Both Citrullus lanatus and Praecitrullus fistulosus have unique variability patterns. Owing to drought tolerating capacity, mateera is the specific land-race of desert eco-system. It is grown rainfed in the kharif and its seeds uniform and khaki in colour. Other-side, watermelon grown in the semi-arid region with irrigations during summer season and seeds much variable and it is mostly developed through introduced varieties. Similarly, tinda is in the same trends and semi-cultivated, tough and dark-green to whitish-green skin types is from the desert eco-system and grown in kharif season. The soft flesh and light-green skin type material grown irrigated during summer in semi-arid climate. Besides, bitter melon or tumba (Citrullus colocynthis) is perennial creeper, wild and found abundant in Thar desert and lesser variability exists. Mostly yellow colour and smooth rind fruits are 6-9 $\mathrm{cm}$ diameter, roundish, biter flesh and lot of seeds. Mateera, tinda and tumba is grown widely on sand-dunes in mixed cropping, and also following a special Bari practices (microcatchments) where about litre water is poured at each seed-sowing point and it is in March month to harvest rainfed produce. Thus, a good number of vegetable potential cropplants are well adapted to dry-land climate. But the marketable quality and yield is marginal in native genetic material and this is due to the problems from abiotic and biotic factors. However, the main cause is nonavailability of desirable genotypes suited to the prevailing climatic conditions and cultivation under resource constraints arid environment. On other side, arid and semi-arid areas of Rajasthan (27.1 million ha \& $79.08 \%$ of the state) is best for quality mateera yield during rainy and summer, and it is due to high temperature, low humidity and plenty of sunshine conditions at fruiting period (Samadia 2007).

\section{Drought tolerant mateera}

Mateera is an indigenous form and drought tolerating watermelon (Citrullus lanatus). It is widely grown in north-western part of India in particular to arid region of Rajasthan during kharif. Mouth appeal of mateera fruit is attributed to sweet taste, aroma and refreshing edible pulp. Ripen fruits consumed fresh as dessert-salad and have juicy and cooling pulp. Tender fruits weighing $100 \mathrm{~g}$ (loiya) are used extensively for vegetable culinary and rayta. Loiya is rich in nutrition and $100 \mathrm{~g}$ fresh weight contains 96.3 $\%$ moisture and $3.7 \%$ dry matter. On percent basis, dry matter contains carbohydrate (35.71), protein (12.15), fat (18.25), crude fibre (25.4), calcium (5.8), phosphorus (0.18) and trace elements (3.3). Seed are protein rich (25-32 \%), roasted and eaten as snacks. Seed also yield nutritive oil (30-40 \%). Seed kernels (magaz) is extracted on large-scale and used in sweets, bakery and ice-creams. Rind of ripen fruits is pickled or turned into sugar-candy (tuty-fruity), and is animal feed too. 
Table 4. Performance of selected $\mathrm{F}_{1}$ hybrids and their parents under hot arid conditions (mean of rainy \& summer season) at Bikaner

\begin{tabular}{|c|c|c|c|c|c|c|c|c|c|}
\hline Parents / hybrids & $\begin{array}{c}\text { Days } \\
\text { to } \\
\text { first } \\
\text { female } \\
\text { flower } \\
\text { (DAS) } \\
\end{array}$ & $\begin{array}{c}\text { Days } \\
\text { to first } \\
\text { harvest } \\
\text { ( DAS) }\end{array}$ & $\begin{array}{l}\text { Number of } \\
\text { marketable } \\
\text { fruits/plant }\end{array}$ & $\begin{array}{c}\text { Fruit } \\
\text { weight } \\
\text { (kg) }\end{array}$ & $\begin{array}{c}\text { Fruit } \\
\text { length } \\
(\mathbf{c m})\end{array}$ & $\begin{array}{l}\text { Fruit } \\
\text { girth } \\
\text { (cm) }\end{array}$ & $\begin{array}{c}\text { TSS } \\
\left({ }^{\circ} \text { Brix }\right)\end{array}$ & $\begin{array}{l}\text { Flesh } \\
\text { colour }\end{array}$ & $\begin{array}{c}\text { Flesh } \\
\text { firmness }\end{array}$ \\
\hline Mateera AHW-19 & $46 . .02$ & 77.00 & 3.82 & 3.84 & 27.86 & 67.31 & 8.06 & $\begin{array}{l}\text { Dark } \\
\text { pink }\end{array}$ & $\begin{array}{l}\text { Semi- } \\
\text { solid }\end{array}$ \\
\hline Mateera AHW-65 & 43.33 & 75.06 & 4.94 & 2.90 & 21.38 & 59.38 & 8.09 & Pink & $\begin{array}{l}\text { Semi- } \\
\text { solid }\end{array}$ \\
\hline Charleston Local & 79.02 & 116.66 & 1.24 & 3.25 & 32.51 & 56.42 & 8.18 & Red & Solid \\
\hline Mahabobi & 84.33 & 115.00 & 1.54 & 2.79 & 26.41 & 59.42 & 8.12 & $\begin{array}{l}\text { Dark } \\
\text { pink }\end{array}$ & Solid \\
\hline Sugar Baby & 72.66 & 102.16 & 1.44 & 2.89 & 26.42 & 61.88 & 9.21 & Red & Solid \\
\hline Durgapura Meetha & 69.05 & 101.20 & 1.69 & 3.44 & 28.54 & 69.32 & 9.45 & Red & Solid \\
\hline $\begin{array}{l}\text { Mateera AHW-19 x } \\
\text { Sugar Baby }\end{array}$ & 54.25 & 95.66 & 5.04 & 3.86 & 29.29 & 60.45 & 5.13 & $\begin{array}{l}\text { Dark } \\
\text { red }\end{array}$ & Solid \\
\hline $\begin{array}{l}\text { Mateera AHW-19 x } \\
\text { Charleston Local }\end{array}$ & 50.12 & 95.12 & 5.13 & 3.27 & 31.98 & 60.98 & 8.20 & Red & Solid \\
\hline $\begin{array}{l}\text { Mateera AHW-65 x } \\
\text { Sugar Baby }\end{array}$ & 57.12 & 100.33 & 4.12 & 3.53 & 27.74 & 62.20 & 6.23 & Red & Solid \\
\hline $\begin{array}{l}\text { Mateera AHW- } 65 \mathrm{x} \\
\text { Charleston Local }\end{array}$ & 54.66 & 98.73 & 6.04 & 2.89 & 27.88 & 56.23 & 8.42 & Red & Solid \\
\hline Mean & 61.03 & 97.67 & 3.50 & 3.26 & 28.02 & 61.36 & 7.91 & - & - \\
\hline $\mathrm{CV}(\%)$ & 1.9 & 1.5 & 1.9 & 2.3 & 1.6 & 1.2 & 0.9 & - & - \\
\hline $\mathrm{CD}(5 \%)$ & 2.02 & 2.54 & 0.11 & 0.13 & 0.77 & 1.25 & 0.13 & - & - \\
\hline
\end{tabular}

Table 5. Genetic variability components for various characters from short-listed mateera/ watermelon germplasm at CIAH, Bikaner

\begin{tabular}{lllllllllll}
\hline Characters & Minimum & Maximum & Mean & $\begin{array}{l}\text { CD } \\
(\mathbf{5 \% )}\end{array}$ & $\begin{array}{l}\text { ECV } \\
(\boldsymbol{\%})\end{array}$ & $\begin{array}{l}\text { GCV } \\
(\boldsymbol{\%})\end{array}$ & $\begin{array}{l}\text { PCV } \\
(\boldsymbol{\%})\end{array}$ & $\begin{array}{l}\mathbf{h}^{2} \\
(\boldsymbol{\%}) \\
\text { (broad } \\
\text { sense) }\end{array}$ & $\begin{array}{l}\text { Genetic } \\
\text { advance } \\
(\mathbf{G A})\end{array}$ & $\begin{array}{l}\text { Genetic } \\
\text { gain } \\
(\mathbf{5 \%} \text { \%) }\end{array}$ \\
\hline DFM & & & & & & & & & & \\
NMF & 34.02 & 54.17 & 44.48 & 0.75 & 1.03 & 11.80 & 11.81 & 99.74 & 10.80 & 24.28 \\
DFF & 43.77 & 67.23 & 52.90 & 1.05 & 1.21 & 11.36 & 11.38 & 99.62 & 12.36 & 23.37 \\
NFF & 6.05 & 21.34 & 12.13 & 0.45 & 2.28 & 28.38 & 28.41 & 99.78 & 7.08 & 58.41 \\
DFH & 76.02 & 114.65 & 88.87 & 1.14 & 0.78 & 11.28 & 11.29 & 99.84 & 20.63 & 23.22 \\
MF/P & 1.03 & 5.45 & 1.90 & 0.09 & 3.06 & 69.67 & 69.69 & 99.94 & 2.73 & 143.47 \\
FY/P & 0.99 & 17.52 & 6.29 & 0.40 & 3.87 & 85.23 & 85.26 & 99.93 & 11.04 & 175.53 \\
FW & 0.78 & 6.81 & 3.10 & 0.10 & 1.98 & 47.89 & 47.91 & 99.94 & 3.06 & 98.64 \\
FL & 16.11 & 44.60 & 26.69 & 0.76 & 1.73 & 25.43 & 25.45 & 99.85 & 13.97 & 52.35 \\
FG & 35.58 & 70.87 & 53.93 & 1.26 & 1.42 & 16.47 & 16.49 & 99.75 & 18.28 & 33.89 \\
EFT & 8.15 & 17.68 & 13.79 & 0.39 & 1.73 & 15.26 & 15.30 & 99.57 & 4.32 & 31.38 \\
NEF & 0.74 & 2.78 & 1.74 & 0.07 & 2.55 & 28.61 & 28.65 & 99.74 & 1.02 & 58.87 \\
TSS & 5.14 & 10.92 & 8.32 & 0.27 & 1.99 & 17.77 & 17.81 & 99.58 & 3.04 & 36.54 \\
VL & 2.50 & 4.48 & 3.08 & 0.15 & 2.96 & 16.30 & 16.39 & 98.91 & 1.02 & 33.39
\end{tabular}




\begin{tabular}{lllllllllll} 
B/P & 4.05 & 6.27 & 5.05 & 0.17 & 2.12 & 13.77 & 13.83 & 99.21 & 1.43 & 28.27 \\
NS/F & 63.32 & 418.55 & 201.90 & 4.23 & 1.27 & 52.24 & 52.25 & 99.98 & 217.29 & 107.62 \\
STW & 2.30 & 12.10 & 6.26 & 0.06 & 0.61 & 37.51 & 37.51 & 99.99 & 4.84 & 77.26 \\
SL & 0.72 & 1.35 & 1.04 & 0.02 & 1.66 & 17.26 & 17.29 & 99.69 & 0.37 & 35.50 \\
SW & 0.43 & 0.85 & 0.63 & 0.01 & 0.93 & 17.96 & 17.97 & 99.91 & 0.23 & 36.98 \\
\hline
\end{tabular}

Where: DFM- Days to first male flower (DAS), NMF- Node to first male flower, DFF- Days to first female flower (DAS), NFF- Node to first female flower, DFH- Days to first harvest (DAS), MF/P- Marketable fruits/ plant (No.), FY/P- Fruit yield/plant $(\mathrm{kg})$, FW- Fruit weight $(\mathrm{kg})$, FL- Fruit length $(\mathrm{cm})$, FG- Fruit girth $(\mathrm{cm})$, EFT- Edible flesh thickness $(\mathrm{cm})$, NEF- Non-edible flesh thickness $(\mathrm{cm})$, TSS $\left({ }^{0}\right.$ Brix), VL-Vine length $(\mathrm{m})$, B/P- Branches/plant (No.), NS/F- Number of seeds/fruit, STW- Seed test weight (g), SL- Seed length (cm) and SW- Seed width (cm).

\section{Why mateera cultivation in arid region?}

For production of mateera, farmer's broad-cast its seeds with mixed cropping of bajra or arid legumes. With good rains, farmer's collected mateera fruits during October-November and it is the period of harvesting kharif crops and fruits ensure income as bonus. In recent years, its cultivation is also popular as sole or inter-crop of orchards. Now, it is grown as irrigated crop in particular for loiya production under extremes of high temperature conditions (Samadia and More 2011). The nonavailability of drought tolerant mateera varieties in the recent past, farmers used heterogeneous and mixed seed collected from cross-pollinated crop and it is based on sweetness of fruits. Intensive studies on flesh character of open-pollinated crops of mateera were done at farmer's fields, and it is concluded that hardly $10 \%$ fruits are marketable quality. Hence, use of such seeds, there is no guarantee of fruit quality prior to cut it. Thus, absence of mateera varieties, productivity and quality is variable and poor. Consequently, it fetches low market price and returns to growers. Likewise, commercial watermelon varieties and hybrids (Durgapura Meetha, Arka Manik, Sugar Baby, Charleston, Mahobobi, Arka Jyoti, etc) needed high and frequent irrigation water, poor yielding and suffer from fruit cracking under high temperature conditions in summers. In rainy season, these genotypes exhibited poor fruit quality and high level of viral complex in plants, and cannot grow under rainfed situation.

\section{Breeding for marketable quality fruits in mateera}

Realizing the importance of drought tolerant and multiple-use mateera in the Indian desert and potentialities to extent its period of fruits availability (April to November), it calls for concerted research. Looking this, systematic work-plan on mateera improvement was taken since 1994 with objectives to develop standard varieties for uniform and quality fruit production including dessert-salad, loiya and high seed content. To fulfill this, intensive surveys were conducted from 1994 to 2002 in arid and semi-arid areas of Rajasthan and wide range of genetic variability was collected in Citrullus species at CIAH. The collected germplasm was characterized, evaluated and utilized in improvement programme over the years (1995 to 2010) and also conserved at national genebank. On evaluation, the collected germplasm exhibited enough variations for agromorphological components of vine, fruit, flesh 
quality and yield attributes. A wide range is recorded for important traits such as days to first male flower appearance (24.5-45.2 DAS), days to first female flower appearance (40.255.5 DAS), node to first female flower (5.418.5), number of fruit-set/plant (3.5-20.8), days to first harvest (72.5-110.5 DAS), number of fruits/plant (0.85-7.45), fruit length $(10.32-40.50 \mathrm{~cm})$, fruit girth (25.91-73.54 $\mathrm{cm})$, fruit weight $(0.50-8.55 \mathrm{~kg})$, TSS $(2.12-$ $10.5^{0}$ Brix), vine length $(2.21-6.50 \mathrm{~m})$ and number of branches/plant (3.12-6.45). Much variability is also recorded for fruit rind, stripes pattern, flesh colour, content and seeds. Both collected and generated material was repeatedly studied for variability parameters and most of the attributes exhibited similar trends under investigation.

Thus, wide-range of variability exists in genotypes under utilization (tables) and it is with respect to growth, flowering, maturity, fruits, flesh quality and seediness besides tolerant to biotic and abiotic factors and which is required for crop improvement. During characterization, Citrullus germplasm were categorized based on economic traits and promising mateera lines viz., AHW-18, AHW-19, AHW-65, AHW-108, AHW-140,
AHW-RSS-1 and AHW-BSM-1 identified. Among watermelon, Sugar Baby, Durgapura Meetha and Charleston Local were potential for flesh firmness and colour under hot arid climate. First time, two high yielding mateera selections namely AHW-19 and AHW-65 developed, released for immediate gains in 1998 and growers accepted it for uniform harvest under rainfed conditions. However, two essential traits of commercial watermelon i.e. eye-appealing flesh quality and sweetness were not materialized in mateera varieties developed by the institute. Therefore, intensive breeding work was done involving AHW-19, AHW-65, Sugar Baby, Durgapura Meetha, Charleston and Mahobobi. First of all, a large number of progenies were generated using selected parentage in combinations $\left(\mathrm{F}_{1}, \mathrm{~F}_{2}, \mathrm{BC}_{1}, \mathrm{BC}_{2}\right.$ and biparental) and evaluated. Simultaneously, requisite segregates isolated from $F_{2}$ to develop individual plant progeny and selfing precedes selection for generation advancement. Four prioritized traits such as flesh quality, earliness, tolerant to cracking and yield behaviour under high temperature and abiotic stressed situations were kept to screen the progenies. 
Journal of Agriculture and Ecology, 2020, Vol. 10, 1-21

http://saaer.org.in

Table 6. Path analysis (direct and indirect) for various characters in short-listed mateera / watermelon germplasm at CIAH, Bikaner

\begin{tabular}{|c|c|c|c|c|c|c|c|c|c|c|c|c|c|c|c|c|c|c|c|}
\hline CHR & DFM & NMF & DFF & NFF & DFH & MF/P & FW & FL & FG & EFT & NEF & TSS & VL & $\mathbf{B} / \mathbf{P}$ & $\mathbf{N S} / \mathbf{F}$ & STW & SL & SW & $\begin{array}{l}\text { FY/P } \\
\text { (GR) }\end{array}$ \\
\hline DFM & $\begin{array}{c}- \\
0.923\end{array}$ & $\begin{array}{c}- \\
0.704\end{array}$ & $\begin{array}{c}- \\
0.827\end{array}$ & $\begin{array}{c}- \\
0.675\end{array}$ & $\begin{array}{c}- \\
0.759\end{array}$ & 0.756 & 0.092 & 0.172 & 0.052 & $\begin{array}{c}- \\
0.044\end{array}$ & 0.114 & 0.041 & 0.145 & .358 & .270 & 131 & 0.230 & $\begin{array}{c}- \\
0.009\end{array}$ & $\begin{array}{c}- \\
0.713\end{array}$ \\
\hline NMF & 0.326 & 0.427 & 0.326 & 0.332 & 0.313 & $\begin{array}{c}- \\
0.250\end{array}$ & $\begin{array}{c}- \\
0.007\end{array}$ & $\begin{array}{c}- \\
0.080\end{array}$ & $\begin{array}{c}- \\
0.036\end{array}$ & $\begin{array}{c}- \\
0.008\end{array}$ & $\begin{array}{c}- \\
0.114\end{array}$ & $\begin{array}{c}- \\
0.045\end{array}$ & $\begin{array}{c}- \\
0.096\end{array}$ & $\begin{array}{c}- \\
0.156\end{array}$ & $\begin{array}{c}- \\
0.091\end{array}$ & 0.043 & $\begin{array}{c}- \\
0.012\end{array}$ & 0.010 & $\overline{-}$ \\
\hline DFF & $\begin{array}{c}- \\
0.820\end{array}$ & $\begin{array}{c}- \\
0.697\end{array}$ & $\overline{-}$ & $\begin{array}{c}- \\
0.704\end{array}$ & $\begin{array}{c}- \\
0.845\end{array}$ & 0.650 & 0.009 & 0.152 & $\begin{array}{c}- \\
0.052\end{array}$ & $\begin{array}{c}- \\
0.073\end{array}$ & $\begin{array}{c}- \\
0.015\end{array}$ & 0.026 & 0.159 & 0.364 & 0.097 & $\begin{array}{c}- \\
0.074\end{array}$ & 0.048 & $\begin{array}{c}- \\
0.142\end{array}$ & $\begin{array}{c}- \\
0.601\end{array}$ \\
\hline NFF & 0.943 & 1.003 & 0.994 & 1.290 & 0.867 & $\begin{array}{c}- \\
0.834\end{array}$ & $\begin{array}{c}- \\
0.151\end{array}$ & $-\overline{4} 46$ & 0.015 & 0.104 & $\begin{array}{c}- \\
0.308\end{array}$ & $\begin{array}{c}- \\
0.035\end{array}$ & $\begin{array}{c}- \\
0.282\end{array}$ & $\begin{array}{c}- \\
0.561\end{array}$ & $\begin{array}{c}- \\
0.451\end{array}$ & 0.208 & $\begin{array}{c}- \\
0.050\end{array}$ & 0.089 & $\begin{array}{c}- \\
0.626\end{array}$ \\
\hline DFH & 1.079 & 0.961 & 1.212 & 0.882 & 1.312 & $\begin{array}{c}- \\
0.739\end{array}$ & $\begin{array}{c}- \\
0.110\end{array}$ & $\overline{-}$ & $\begin{array}{c}- \\
0.069\end{array}$ & $\begin{array}{c}- \\
0.044\end{array}$ & $\begin{array}{c}- \\
0.173\end{array}$ & 0.021 & $\overline{-}$ & $\begin{array}{c}- \\
0.411\end{array}$ & $\begin{array}{c}- \\
0.123\end{array}$ & 0.182 & $\begin{array}{c}- \\
0.034\end{array}$ & 0.221 & $\begin{array}{c}- \\
0.516\end{array}$ \\
\hline $\mathrm{MF} / \mathrm{P}$ & $\begin{array}{c}- \\
1.711\end{array}$ & $\begin{array}{c}- \\
1.222\end{array}$ & $\begin{array}{c}- \\
1.483\end{array}$ & $\begin{array}{c}- \\
1.350\end{array}$ & $\begin{array}{c}- \\
1.176\end{array}$ & 2.088 & 0.271 & 0.301 & 0.370 & 0.087 & 0.049 & 0.426 & 0.878 & 0.940 & 1.101 & 0.838 & 1.045 & 0.674 & 0.887 \\
\hline FW & 0.002 & 0.000 & 0.000 & 0.003 & 0.002 & $\begin{array}{c}- \\
0.003\end{array}$ & $\overline{0.028}$ & $\begin{array}{c}- \\
0.023\end{array}$ & $\begin{array}{c}- \\
0.024\end{array}$ & $\begin{array}{c}- \\
0.021\end{array}$ & $\begin{array}{c}- \\
0.017\end{array}$ & $\begin{array}{c}- \\
0.002\end{array}$ & $\begin{array}{c}- \\
0.002\end{array}$ & $\begin{array}{c}- \\
0.000\end{array}$ & $\begin{array}{c}- \\
0.013\end{array}$ & 0.004 & 0.002 & 0.005 & 0.491 \\
\hline FL & $\overline{-}$ & $\begin{array}{c}- \\
0.304\end{array}$ & $\begin{array}{c}- \\
0.268\end{array}$ & $\begin{array}{c}- \\
0.560\end{array}$ & $\overline{-}$ & 0.233 & 1.315 & 1.617 & 1.109 & 0.99 & 0.751 & 0.023 & 0.062 & 0.274 & 0.834 & $\begin{array}{c}- \\
0.368\end{array}$ & $\begin{array}{c}- \\
0.200\end{array}$ & $\begin{array}{c}- \\
0.335\end{array}$ & 0.441 \\
\hline FG & $\begin{array}{c}- \\
0.038\end{array}$ & $\begin{array}{c}- \\
0.057\end{array}$ & 0.039 & 0.008 & $\begin{array}{c}- \\
0.035\end{array}$ & 0.120 & 0.578 & 0.464 & 0.677 & 0.549 & 0.352 & 0.135 & 0.256 & 0.035 & 0.375 & 0.018 & 0.050 & 0.038 & 0.473 \\
\hline EFT & $\begin{array}{c}- \\
0.072\end{array}$ & 0.029 & $\begin{array}{c}- \\
0.122\end{array}$ & $\begin{array}{c}- \\
0.123\end{array}$ & 0.051 & $\begin{array}{c}- \\
0.063\end{array}$ & $\begin{array}{c}- \\
1.168\end{array}$ & $\begin{array}{c}- \\
0.934\end{array}$ & $\begin{array}{c}- \\
1.232\end{array}$ & $\begin{array}{c}- \\
1.519\end{array}$ & $\begin{array}{c}- \\
0.882\end{array}$ & $\begin{array}{c}- \\
0.558\end{array}$ & $\begin{array}{c}- \\
0.283\end{array}$ & 0.315 & $\begin{array}{c}- \\
0.344\end{array}$ & $\begin{array}{c}- \\
0.022\end{array}$ & $\begin{array}{c}- \\
0.114\end{array}$ & 0.035 & 0.398 \\
\hline NEF & $\begin{array}{c}- \\
0.085\end{array}$ & $\begin{array}{c}- \\
0.184\end{array}$ & 0.011 & $\begin{array}{c}- \\
0.164\end{array}$ & $\begin{array}{c}- \\
0.091\end{array}$ & 0.016 & 0.418 & 0.320 & 0.359 & 0.401 & 0.690 & $\begin{array}{c}- \\
0.052\end{array}$ & 0.092 & $\begin{array}{c}- \\
0.157\end{array}$ & 0.197 & 0.031 & 0.058 & 0.064 & 0.344 \\
\hline TSS & $\begin{array}{c}- \\
0.012\end{array}$ & $\begin{array}{c}- \\
0.030\end{array}$ & $\begin{array}{c}- \\
0.008\end{array}$ & $\begin{array}{c}- \\
0.007\end{array}$ & 0.004 & 0.058 & 0.029 & 0.004 & 0.057 & 0.105 & $\begin{array}{c}- \\
0.021\end{array}$ & 0.287 & 0.060 & 0.030 & 0.016 & 0.011 & 0.048 & 0.002 & 0.254 \\
\hline VL & $\begin{array}{c}- \\
0.020\end{array}$ & $\begin{array}{c}- \\
0.029\end{array}$ & $\begin{array}{c}- \\
0.022\end{array}$ & $\begin{array}{c}- \\
0.028\end{array}$ & $\begin{array}{c}- \\
0.012\end{array}$ & 0.054 & 0.019 & 0.005 & 0.048 & 0.024 & 0.017 & 0.027 & 0.129 & 0.056 & 0.028 & 0.025 & 0.032 & 0.034 & 0.503 \\
\hline $\mathrm{B} / \mathrm{P}$ & 0.341 & 0.323 & 0.351 & 0.383 & 0.276 & $\begin{array}{c}- \\
0.396\end{array}$ & $\begin{array}{c}- \\
0.021\end{array}$ & $\begin{array}{c}- \\
0.149\end{array}$ & $\begin{array}{c}- \\
0.045\end{array}$ & 0.182 & 0.201 & $\begin{array}{c}- \\
0.094\end{array}$ & $\begin{array}{c}- \\
0.384\end{array}$ & $\begin{array}{c}- \\
0.880\end{array}$ & $\begin{array}{c}- \\
0.064\end{array}$ & 0.142 & 0.056 & 0.084 & 0.352 \\
\hline $\mathrm{NS} / \mathrm{F}$ & 0.470 & 0.344 & 0.170 & 0.562 & 0.151 & $\begin{array}{c}- \\
0.847\end{array}$ & $\begin{array}{c}- \\
0.738\end{array}$ & $\begin{array}{c}- \\
0.828\end{array}$ & $\begin{array}{c}- \\
0.890\end{array}$ & $\begin{array}{c}- \\
0.363\end{array}$ & $\begin{array}{c}- \\
0.459\end{array}$ & $\begin{array}{c}- \\
0.094\end{array}$ & $\begin{array}{c}- \\
0.352\end{array}$ & $\begin{array}{c}- \\
0.117\end{array}$ & $\begin{array}{c}- \\
1.606\end{array}$ & $\begin{array}{c}- \\
0.599\end{array}$ & $\begin{array}{c}- \\
0.749\end{array}$ & $\begin{array}{c}- \\
0.755\end{array}$ & 0.596 \\
\hline STW & 0.480 & $\begin{array}{c}- \\
0.342\end{array}$ & $\begin{array}{c}- \\
0.274\end{array}$ & $\begin{array}{c}- \\
0.546\end{array}$ & $\begin{array}{c}- \\
0.471\end{array}$ & $\begin{array}{c}- \\
1.359\end{array}$ & 0.514 & 0.771 & $\begin{array}{c}- \\
0.091\end{array}$ & $\begin{array}{c}- \\
0.050\end{array}$ & $\begin{array}{c}- \\
0.151\end{array}$ & $\begin{array}{c}- \\
0.132\end{array}$ & $\begin{array}{c}- \\
0.662\end{array}$ & 0.547 & $\begin{array}{c}- \\
1.263\end{array}$ & $\begin{array}{c}- \\
3.387\end{array}$ & $\begin{array}{c}- \\
3.128\end{array}$ & $\begin{array}{c}- \\
3.017\end{array}$ & 0.340 \\
\hline SL & $\begin{array}{c}- \\
0.390\end{array}$ & $\begin{array}{c}- \\
0.046\end{array}$ & $\begin{array}{c}- \\
0.083\end{array}$ & $\begin{array}{c}- \\
0.060\end{array}$ & $\begin{array}{c}- \\
0.040\end{array}$ & 0.784 & $\begin{array}{c}- \\
0.155\end{array}$ & $\begin{array}{c}- \\
0.194\end{array}$ & 0.117 & 0.118 & 0.132 & 0.264 & 0.391 & $\begin{array}{c}- \\
0.100\end{array}$ & 0.730 & 1.447 & 1.566 & 1.341 & 0.492 \\
\hline SW & 0.018 & 0.045 & 0.298 & 0.133 & 0.324 & 0.619 & $\begin{array}{c}- \\
0.376 \\
\end{array}$ & $\begin{array}{c}- \\
0.397 \\
\end{array}$ & 0.108 & $\begin{array}{c}- \\
0.044 \\
\end{array}$ & 0.178 & 0.015 & 0.515 & $\begin{array}{c}- \\
0.184 \\
\end{array}$ & 0.902 & 1.708 & 1.642 & 1.918 & 0.262 \\
\hline
\end{tabular}


Table 7. Genotypic (above) and phenotypic (below) correlation co-efficient among various characters in short-listed mateera / watermelon

\begin{tabular}{|c|c|c|c|c|c|c|c|c|c|c|c|c|c|c|c|c|c|c|c|}
\hline CHR & DFM & NMF & DFF & NFF & DFH & MF/P & FY/P & FW & FL & FG & EFT & NEF & TSS & VL & $\mathbf{B} / \mathbf{P}$ & $\mathbf{N S} / \mathbf{F}$ & STW & SL & SW \\
\hline DFM & 1.000 & 0.763 & 0.896 & 0.731 & 0.822 & $\begin{array}{l}- \\
0.819\end{array}$ & $\begin{array}{l} \\
0.713\end{array}$ & $\begin{array}{l}- \\
0.100\end{array}$ & $\begin{array}{l}- \\
0.186\end{array}$ & $\begin{array}{l}- \\
0.056\end{array}$ & 0.047 & $\begin{array}{l}- \\
0.124\end{array}$ & $\begin{array}{l}- \\
0.044\end{array}$ & $\begin{array}{l}- \\
0.157\end{array}$ & $\begin{array}{l}- \\
0.388\end{array}$ & $\begin{array}{l}- \\
0.292\end{array}$ & $\begin{array}{l}- \\
0.141\end{array}$ & $\begin{array}{l}- \\
0.249\end{array}$ & 0.009 \\
\hline NMF & 0.761 & 1.000 & 0.762 & 0.777 & 0.732 & $\begin{array}{l}- \\
0.585\end{array}$ & $\begin{array}{l}- \\
0.485\end{array}$ & $\begin{array}{l}- \\
0.017\end{array}$ & $\begin{array}{l}- \\
0.188\end{array}$ & $\begin{array}{l}- \\
0.084\end{array}$ & $\begin{array}{l}- \\
0.019\end{array}$ & 0.266 & $\begin{array}{l}- \\
0.106\end{array}$ & $\begin{array}{l}- \\
0.225\end{array}$ & $\begin{array}{l}- \\
0.366\end{array}$ & $\begin{array}{l}- \\
0.214\end{array}$ & 0.101 & $\begin{array}{l}- \\
0.029\end{array}$ & 0.023 \\
\hline DFF & 0.893 & 0.759 & 1.000 & 0.770 & 0.924 & 0.710 & - & 0.010 & 0.166 & 0.057 & 0.080 & 0.017 & $\begin{array}{l}- \\
0.028\end{array}$ & $\begin{array}{l}- \\
0.173\end{array}$ & $-\overline{0.398}$ & 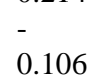 & 0.080 & -0.053 & 0.155 \\
\hline NFF & 0.729 & 0.776 & 0.768 & 1.000 & 0.672 & $\begin{array}{l}- \\
0.646\end{array}$ & $\begin{array}{l}- \\
0.626\end{array}$ & $\begin{array}{l}- \\
0.117\end{array}$ & $\begin{array}{l}- \\
0.346\end{array}$ & 0.012 & 0.081 & $\begin{array}{l}- \\
0.238\end{array}$ & $\begin{array}{l}- \\
0.027\end{array}$ & $\begin{array}{l}- \\
0.218\end{array}$ & $\begin{array}{l}- \\
0.435\end{array}$ & $\begin{array}{l}- \\
0.350\end{array}$ & 0.161 & $\begin{array}{l}- \\
0.038\end{array}$ & 0.069 \\
\hline DFH & 0.821 & 0.730 & 0.921 & 0.671 & 1.000 & $-\overline{0.563}$ & $\begin{array}{l}- \\
0.516\end{array}$ & $\begin{array}{l}- \\
0.084\end{array}$ & $\overline{0}-238$ & $\begin{array}{l}- \\
0.053\end{array}$ & $-\overline{0}$ & $\begin{array}{l}- \\
0.132\end{array}$ & 0.016 & $\begin{array}{l}- \\
0.092\end{array}$ & $\begin{array}{l}- \\
0.313\end{array}$ & $\begin{array}{l}- \\
0.094\end{array}$ & 0.139 & $\begin{array}{l}- \\
0.025\end{array}$ & 0.169 \\
\hline $\mathrm{MF} / \mathrm{P}$ & $-\overline{0.818}$ & $\overline{-}$ & $\begin{array}{l}- \\
0.709\end{array}$ & $-\overline{0.645}$ & $-\overline{0.562}$ & 1.000 & 0.887 & 0.130 & 0.144 & 0.177 & 0.041 & 0.023 & 0.204 & 0.420 & 0.450 & 0.527 & 0.401 & 0.500 & 0.323 \\
\hline FY/P & $\begin{array}{l}- \\
0.712\end{array}$ & $\begin{array}{l}- \\
0.484\end{array}$ & $\begin{array}{l}- \\
0.599\end{array}$ & $\begin{array}{l}- \\
0.625\end{array}$ & $\begin{array}{l}- \\
0.515\end{array}$ & 0.887 & 1.000 & 0.491 & 0.441 & 0.473 & 0.398 & 0.344 & 0.254 & 0.503 & 0.352 & 0.596 & 0.340 & 0.492 & 0.262 \\
\hline FW & $\begin{array}{l}- \\
0.100\end{array}$ & $\begin{array}{l}- \\
0.017\end{array}$ & 0.009 & $\begin{array}{l}- \\
0.117\end{array}$ & $\begin{array}{l}- \\
0.084\end{array}$ & 0.129 & 0.490 & 1.000 & 0.813 & 0.854 & 0.769 & 0.605 & 0.102 & 0.149 & 0.024 & 0.459 & $\begin{array}{l}- \\
0.151\end{array}$ & $\begin{array}{l}- \\
0.098\end{array}$ & $\begin{array}{l}- \\
0.196\end{array}$ \\
\hline FL & $\begin{array}{l}- \\
0.186\end{array}$ & $\begin{array}{l}- \\
0.187\end{array}$ & $\begin{array}{l}- \\
0.165\end{array}$ & $\begin{array}{l}- \\
0.345\end{array}$ & $\begin{array}{l}- \\
0.238\end{array}$ & 0.144 & 0.441 & 0.812 & 1.000 & 0.685 & 0.615 & 0.464 & 0.014 & 0.038 & 0.169 & 0.515 & $\begin{array}{l}- \\
0.227\end{array}$ & $\begin{array}{l}- \\
0.124\end{array}$ & $\begin{array}{l}- \\
0.207\end{array}$ \\
\hline FG & $\begin{array}{l}- \\
0.056\end{array}$ & $\begin{array}{l}- \\
0.084\end{array}$ & 0.058 & 0.012 & $\begin{array}{l}- \\
0.053\end{array}$ & 0.177 & 0.472 & 0.853 & 0.684 & 1.000 & 0.811 & 0.520 & 0.200 & 0.378 & 0.052 & 0.554 & 0.027 & 0.074 & 0.056 \\
\hline EFT & 0.048 & $\begin{array}{l}- \\
0.019\end{array}$ & 0.079 & 0.081 & $\begin{array}{l}- \\
0.034\end{array}$ & 0.041 & 0.397 & 0.767 & 0.612 & 0.808 & 1.000 & 0.580 & 0.367 & 0.186 & $\begin{array}{l}- \\
0.207\end{array}$ & 0.226 & 0.014 & 0.075 & $\begin{array}{l}- \\
0.023\end{array}$ \\
\hline NEF & $\begin{array}{l}- \\
0.124\end{array}$ & $\begin{array}{l}- \\
0.266\end{array}$ & 0.016 & $\begin{array}{l}- \\
0.238\end{array}$ & $\begin{array}{l}- \\
0.132\end{array}$ & 0.023 & 0.344 & 0.604 & 0.463 & 0.519 & 0.578 & 1.000 & $\begin{array}{l}- \\
0.075\end{array}$ & 0.133 & $\begin{array}{l}- \\
0.228\end{array}$ & 0.285 & 0.044 & 0.084 & 0.093 \\
\hline TSS & - & $\begin{array}{l}- \\
0.106\end{array}$ & $\begin{array}{l}- \\
0.027\end{array}$ & $\begin{array}{l}- \\
0.027\end{array}$ & 0.017 & 0.203 & 0.253 & 0.101 & 0.014 & 0.200 & 0.366 & $-\overline{0.076}$ & 1.000 & 0.209 & 0.107 & 0.058 & .039 & 0.168 & 0.007 \\
\hline VL & $\begin{array}{l}- \\
0.156\end{array}$ & $\begin{array}{l}- \\
0.224\end{array}$ & $\begin{array}{l}- \\
0.173\end{array}$ & $\begin{array}{l}- \\
0.217\end{array}$ & $\begin{array}{l}- \\
0.091\end{array}$ & 0.418 & 0.501 & 0.147 & 0.039 & 0.375 & 0.185 & 0.133 & 0.207 & 1.000 & 0.436 & 0.219 & 0.195 & 0.250 & 0.268 \\
\hline $\mathrm{B} / \mathrm{P}$ & $\begin{array}{l}- \\
0.386\end{array}$ & $\begin{array}{l}- \\
0.365\end{array}$ & $\begin{array}{l}- \\
0.396\end{array}$ & $\begin{array}{l}- \\
0.432\end{array}$ & $\begin{array}{l}- \\
0.312\end{array}$ & 0.448 & 0.351 & 0.024 & 0.168 & 0.051 & $\begin{array}{l}- \\
0.206\end{array}$ & $\begin{array}{l}- \\
0.225\end{array}$ & 0.103 & 0.433 & 1.000 & 0.073 & $\begin{array}{l}- \\
0.161\end{array}$ & $\begin{array}{l}- \\
0.064\end{array}$ & $\begin{array}{l}- \\
0.096\end{array}$ \\
\hline $\mathrm{NS} / \mathrm{F}$ & $\begin{array}{l}- \\
0.292\end{array}$ & $\begin{array}{l}- \\
0.214\end{array}$ & $\begin{array}{l}- \\
0.105\end{array}$ & $\begin{array}{l}- \\
0.349\end{array}$ & $\begin{array}{l}- \\
0.094\end{array}$ & 0.527 & 0.595 & 0.459 & 0.515 & 0.553 & 0.225 & 0.285 & 0.058 & 0.218 & 0.072 & 1.000 & 0.372 & 0.466 & 0.470 \\
\hline STW & $\begin{array}{l}- \\
0.141\end{array}$ & 0.101 & 0.080 & 0.161 & 0.138 & 0.401 & 0.340 & $\begin{array}{l}- \\
0.151\end{array}$ & $\begin{array}{l}- \\
0.227\end{array}$ & 0.027 & 0.014 & 0.044 & 0.038 & 0.194 & $\begin{array}{l}- \\
0.160\end{array}$ & 0.372 & 1.000 & 0.923 & 0.890 \\
\hline SL & $\begin{array}{l}- \\
0.248\end{array}$ & $\begin{array}{l}- \\
0.029\end{array}$ & $\begin{array}{l}- \\
0.054\end{array}$ & $\begin{array}{l}- \\
0.038\end{array}$ & $\begin{array}{l}- \\
0.025\end{array}$ & 0.500 & 0.492 & $\begin{array}{l}- \\
0.099\end{array}$ & $\begin{array}{l}- \\
0.123\end{array}$ & 0.073 & 0.074 & 0.085 & 0.167 & 0.249 & $\begin{array}{l}- \\
0.063\end{array}$ & 0.465 & 0.921 & 1.000 & 0.856 \\
\hline SW & 0.009 & 0.023 & 0.155 & 0.069 & 0.168 & 0.322 & 0.261 & $\begin{array}{l}- \\
0.195\end{array}$ & $\begin{array}{l}- \\
0.207\end{array}$ & 0.056 & $\begin{array}{l}- \\
0.023\end{array}$ & 0.092 & 0.007 & 0.266 & $\begin{array}{l}- \\
0.095\end{array}$ & 0.470 & 0.890 & 0.854 & 1.000 \\
\hline
\end{tabular}


The desirable progenies and their derivates were advanced over the years and evaluated both rainy and summer of 2000 to 2004. Fruit quality, fruiting behaviour, reaction to cracking, insects and diseases were taken into consideration to screen the developed progenies. In $\mathrm{F}_{6}$ generation, few progenies of cross combination of AHW-19 x Sugar Baby exhibited desirable trends for fruit flesh (colour, firmness, content and TSS) and yield. After assessing fruit quality components among $\mathrm{F}_{6 / \mathrm{a}}$ family, four blocks $\left(\mathrm{F}_{6} / \mathrm{a} / 3, \mathrm{~F}_{6} / \mathrm{a} / 7\right.$, $\mathrm{F}_{6} / \mathrm{a} / 9$ and $\mathrm{F}_{6} / \mathrm{a} / 10$ ) were developed and advanced for uniformity. On evaluation, these showed desirable trends for earliness, number of marketable fruits/plant, fruit size, shape and flesh quality. The fruit quality and yield components of advanced family $\mathrm{F}_{6} / \mathrm{a} / 10$ was much superior and highly acceptable depicting internally as good Sugar Baby and rind characters as mateera. This was further advanced in isolation and open-pollinated progeny named $\mathrm{F}_{6} / \mathrm{a}$ (Thar Manak) and released in 2007. The developed variety is devoid of cracking and suitable for springsummer and rainy season cultivation under hot arid climate.

Table 8. Range values of characters in advanced progenies from cross combination of AHW-19 $\mathrm{x}$ Sugar Baby selected for fruit quality improvement in drought tolerant mateera at CIAH, Bikaner

\begin{tabular}{|c|c|c|c|c|c|c|}
\hline Generation & $\mathbf{F}_{2}$ & $\mathbf{F}_{3}$ & $\mathbf{F}_{4}$ & $\mathbf{F}_{5}$ & $\mathbf{F}_{6}$ & $\mathbf{F}_{6}$ \\
\hline Season/year & Rainy & Summer & Rainy & Summer & Rainy & Summer \\
\hline Character & 1999 & 2000 & 2000 & 2001 & 2001 & 2002 \\
\hline $\begin{array}{l}\text { Days to first female } \\
\text { flower (DAS) }\end{array}$ & $41.2-51.5$ & $40.2-55.1$ & $41.7-57.2$ & $\begin{array}{c}46.2- \\
58.6\end{array}$ & $32.5-38.9$ & $40.1-44.2$ \\
\hline $\begin{array}{l}\text { Days to first harvest } \\
\text { (DAS) }\end{array}$ & $75.5-95.2$ & $75.4-92.1$ & 72.4.-98.6 & $\begin{array}{l}75.4- \\
94.2\end{array}$ & $70.4-74.6$ & $74.1-76.2$ \\
\hline $\begin{array}{l}\text { Number of fruits-set/ } \\
\text { plant }\end{array}$ & $8.5-11.4$ & $7.3-13.2$ & $6.5-13.2$ & $6.2-14.0$ & $10.5-16.4$ & $11.1-14.2$ \\
\hline $\begin{array}{l}\text { No. of marketable } \\
\text { fruits/ plant }\end{array}$ & $2.1-4.2$ & $1.5-5.6$ & $2.5-5.1$ & $3.2-5.0$ & $3.5-5.0$ & $3.6-4.6$ \\
\hline Vine length (m) & $2.5-3.5$ & $2.4-3.8$ & $2.5-3.2$ & $2.1-2.9$ & $3.1-3.9$ & $3.1-3.6$ \\
\hline $\begin{array}{l}\text { Number of branches/ } \\
\text { plant }\end{array}$ & $4.2-6.4$ & $4.1-6.5$ & $4.2-6.2$ & $4.2-5.8$ & $5.5-6.2$ & $5.4-6.0$ \\
\hline Fruit weight (kg) & $1.5-4.5$ & $2.5-5.6$ & $1.8-5.7$ & $2.0-3.9$ & $4.9-5.2$ & $4.5-5.2$ \\
\hline Fruit length $(\mathrm{cm})$ & $13.4-28.5$ & $20.1-28.3$ & $19.4-29.6$ & $\begin{array}{l}12.9- \\
24.5\end{array}$ & $20.1-24.5$ & $20.3-25.1$ \\
\hline Fruit girth $(\mathrm{cm})$ & $48.5-64.5$ & $52.4-68.4$ & $54.2-66.1$ & $\begin{array}{c}50.2- \\
63.4\end{array}$ & $62.4-66.8$ & $57.2-68.4$ \\
\hline $\begin{array}{l}\text { Edible flesh thickness } \\
(\mathrm{cm})\end{array}$ & $11.5-16.4$ & $12.2-19.4$ & $12.8-20.4$ & $\begin{array}{c}13.7- \\
17.4\end{array}$ & $16.5-18.4$ & $16.5-19.2$ \\
\hline $\begin{array}{l}\text { Non-edible flesh } \\
\text { thickness }(\mathrm{cm})\end{array}$ & $1.1-2.4$ & $1.2-2.3$ & $1.1-2.3$ & $1.1-2.2$ & $1.5-1.8$ & $1.9-2.1$ \\
\hline $\operatorname{TSS}\left({ }^{0}\right.$ Brix $)$ & $10.2-13.5$ & $7.0-12.8$ & $7.8-13.2$ & $\begin{array}{l}10.1- \\
12.8\end{array}$ & $10.5-11.8$ & $10.2-12.8$ \\
\hline Fruit shape & Round, & Round, & Round, & Round, & Oblong & Oblong \\
\hline
\end{tabular}




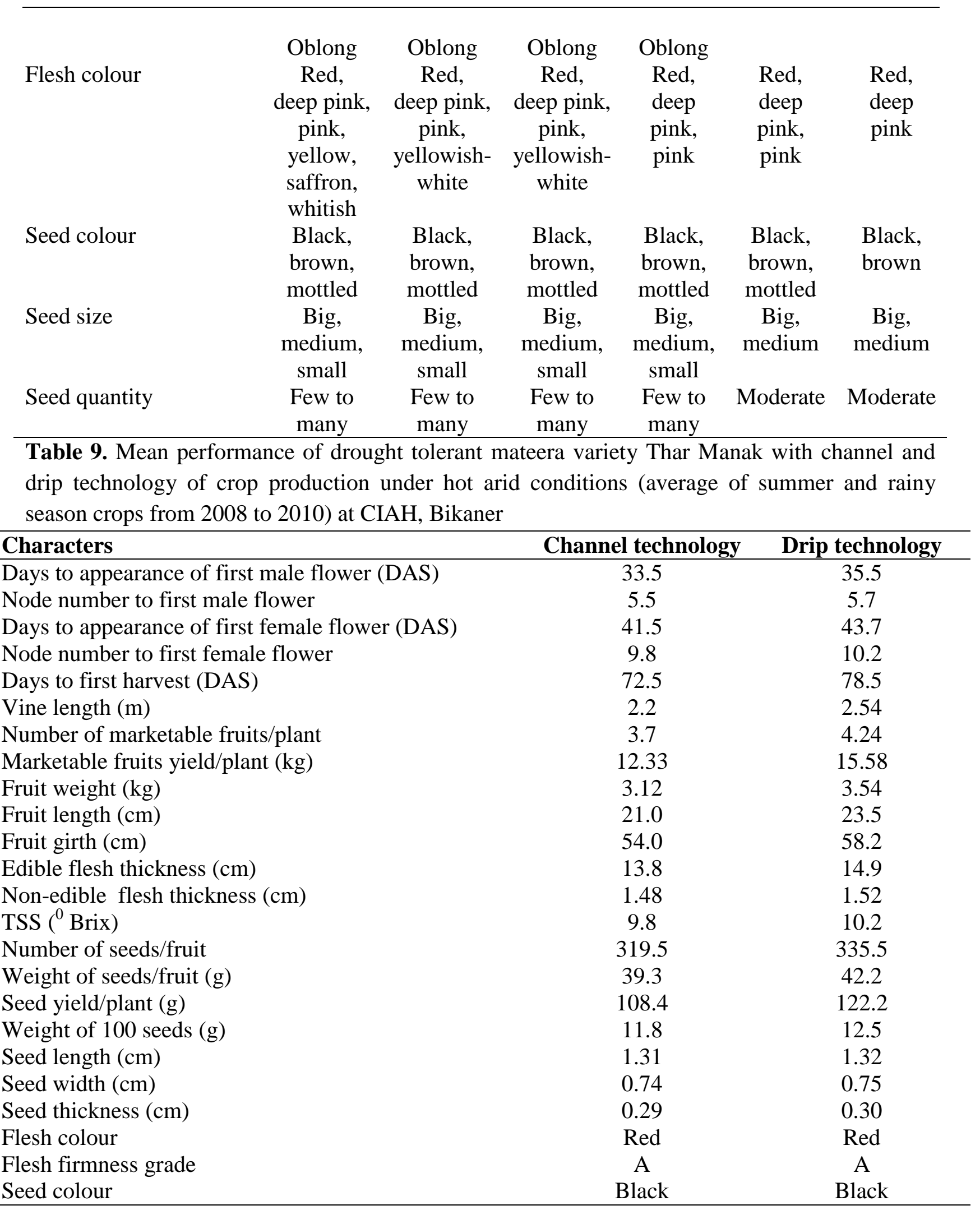




\section{AHW-19}

It is multiple-use selection and rainfed cultivation. Appearance of first female flower starts at 45 days and tender fruits (loiya) ready for harvesting from 58 days of sowing. Ripen fruits ready for first harvesting at 75-77 DAS, and are $3.8-4.1 \mathrm{~kg}$ weight, $30-33 \mathrm{~cm}$ length and $60-65 \mathrm{~cm}$ girth. Oblong shape fruits have dark green-green clear stripes on the smooth rind. It bears 3.1-3.4 ripen fruits/ plant and yielded 192-386 q/ha. Flesh pink, firm, good taste and 8.0-8.4 \% sweetness. High in seeds, 489-527 number/ fruit and weight of 100 seeds is 9.12-9.27 g. Seed bold and khaki in colour.

\section{AHW-65}

It is dual-purpose selection and early in fruit harvesting under rainfed conditions. Medium growth vines $3.1 \mathrm{~m}$ length and producing andromonoecious flowers resulting to higher fruit setting. Tender loiya harvesting starts at 55 days and ripen fruits from 72 days after sowing. It bears 3.7-4.2 fruits/ plant and yields 182-341 q/ha. Mature fruits are round, green stripes on smooth rind, medium sized and $2.8 \mathrm{~kg}$ weight, 25-29 cm length and 58-61 $\mathrm{cm}$ girth. Ripen fruits have $14-15 \mathrm{~cm}$ edible flesh and 1.5-1.7 cm non-edible flesh. Flesh is pink, firm, sweet and 8.0-8.5 \% TSS. The fruit have excellent keeping and transport quality

\section{Thar Manak}

It is wider acceptable fruit quality selection and tolerant to drought, high temperature and abiotic stressed conditions. It is through hybridization from cross combination of AHW-19 x Sugar Baby. It is early in first harvesting (75 DAS) and high yielding (185-355 q/ ha). Ripen fruits are oblong-round with dark green-green stripes on smooth rind. Fruits weighing $2.65-4.21 \mathrm{~kg}$ are 20-22 cm length and 58-62 cm girth, and free from cracking. Flesh is attractive, reddish, firm, granular and 9.5-11.2\% TSS. Seeds very big, bold, black and low (160-266 number/ fruit). It is suitable for summer and rainy season irrigated crop and also rainfed cultivation during kharif.

\section{AHW-RSS-1}

It is trait specific selection from native germplasm and stabilized in 2012 for high seed yield under rainfed conditions. It is short duration, harvesting starts at 80 days and vine bears 3.2 mature fruits. Fruit is big and oblong shape with non-stripe light green and smooth rind. Ripen fruits $7.9 \mathrm{~kg}$ weight, $32 \mathrm{~cm}$ length and $68 \mathrm{~cm}$ girth. Edible flesh firm but white in colour, $15.5 \mathrm{~cm}$ thick and non-edible is $2.5 \mathrm{~cm}$ wide. Fruit very high in seeds (950-1120 number), weight of 100 seeds is $9.8 \mathrm{~g}$ and yield 295-335 g/plant. Seed big, bold and reddish in colour.

\section{AHW-BSM-1}

It is black seeded mutant spotted in 2005 from AHW-19 crop and selected in 2012 for multiple-use, high seed-yield and rainfed cultivation. Harvesting starts from 80 days and vine bears 2.5 fruits and yield is $11.0 \mathrm{~kg} /$ plant. Fruits medium sized, oblong with green-dark green stripes and smooth rind. Ripen fruits 4.4 $\mathrm{kg}$ weight, $22.4 \mathrm{~cm}$ length and $61.6 \mathrm{~cm}$ girth. Edible flesh is firm, pink, $16.8 \mathrm{~cm}$ thick and non-edible $1.2 \mathrm{~cm}$ wide. Fruits high in seed (891 numbers) and $214 \mathrm{~g} / \mathrm{plant}$ yield. Seed is big, bold and black in colour.

\section{Future strategies}

Breeding for improvement in fruit quality and productivity is a continuous nature of work to ensure genotypes for cultivation 
under high temperature, drought, low-rains / water and suitability to organic, off-season or prolonged period of harvesting. In addition, increased Citrullus demand invites timely resetting of priority and the breeding programmes should be focused through use of native germplasm and value-added genotypes developed else-where. Since, the existing genotypes are susceptible to virus complexes, temperature and abiotic stresses of hot arid conditions. Based on gap analysis in germplasm utilization over 25 years at CIAH, some issues have been identified for in-depth analysis and strengthening the activities:-

a) Utilization of regional and national genetic resources of mateera/ watermelon for breeding high temperature stresses tolerant genotypes with better quality marketable fruit yield under varying production environment,

b) Utilization of indigenous mateera germplasm to develop trait-specific/ valueadded genotypes such as loiya and seedkernels for production under rainfed and abiotic stresses conditions, and its promotion through seed-chain due to their regional preferences,

c) Distant hybridization and combination breeding using mateera and tumba genepool to develop viruses tolerant watermelon genotypes for cultivation under abiotic and biotic stresses areas,

d) Conservation and use of native Citrullus germplasm for breeding varieties and cultivation under low-input, organic, rainfed, surface-covering protective technique as mechanism of escaping severity of winter for short-period and vertical harvesting under hot arid climate.

\section{References}

Anonymous. 1994-2019. Annual reports. National Research Centre for Arid Horticulture / Central Institute for Arid Horticulture (ICAR), Bikaner (Rajasthan) India.

Anonymous. 2005. Final report - NATP on sustainable management of plant biodiversity - Collection, evaluation and maintenance of arid horticultural crops. Co-operating centre of NBPGR, Central Institute for Arid Horticulture (ICAR), Bikaner (Rajasthan) India.

Choudhary BR, Haldhar SM, Maheshwari SK, Bhargava R \& Sharma SK. 2015. Phytochemicals and antioxidants in watermelon (Citrullus lanatus) genotypes under hot arid region. Indian Journal of Agricultural Sciences 85 (3): 414-417.

Dwivedi NK, Bhandari DC, Bhatnagar N \& Samadia DK. 2003. Diversity of kachri and mateera in arid region of Rajasthan. In: Human impact on desert environment (eds. Naraian, Pratap, S. Kathju, Amar Kar, M. P. Singh and Praveen Kumar). Arid Zone Research Association of India and Scientific Publishers (India) Jodhpur (India). pp478-482.

Haldhar SM, Choudhary BR \& Bhargava R. 2016. Susceptibility of watermelon genotypes to fruit fly bactrocera cucurbitae (coquillett). Indian Journal of Entomology, 78(2): 170-173.

Haldhar SM, Choudhary BR, Bhargava R \& Meena SR. 2015. Antixenotic and allelochemical resistance traits of watermelon against Bactrocera 
cucurbitae in a hot arid region of India.

Florida Entomologist, 98(3): 827-834.

Pareek OP \& Samadia DK. 1999. Watermelon (mateera) varieties developed by NRCAH. ICAR NEWS, 5 (2): 14-15.

Pareek OP, Vashishtha BB \& Samadia DK. 1999. Genetic diversity in drought hardy cucurbits from hot arid zone of India. IPGRI-APO Regional Newsletter for Asia, the Pacific and Oceania, 28: 22-23.

Pareek OP, Vashishtha BB, Vishalnath, Samadia DK \& Singh RS. 1999. Horticultural resources in Thar dessert. In: Natural resources in Rajasthan (eds. Anil Kumar, Rajesh Sharma and Madhu Sharma), SKRAU, Bikaner. pp4-9.

Pareek, O.P. and Samadia, D.K. (2002). Promising indigenous cucurbit varieties. Indian Horticulture, 47 (2): 15-18.

Samadia DK \& Haldhar SM. 2017. Breeding strategies and scope of improvement in arid zone fruit crop-plant under abiotic stressed agro-climate: an analysis. Journal of Agriculture and Ecology, 4: $1-13$.

Samadia DK \& Haldhar SM. 2019. Scope and strategies for genetic improvement in vegetable crop-plants under high temperature and abiotic stressed climate of Rajasthan: A gap analysis. Journal of Agriculture and Ecology, 8: 1-18.

Samadia DK \& Pareek OP. 1996. Variability in drought hardy watermelon (Citrullus lanatus) type mateera in arid eco-system. Abstract of paper In: Second International Crop Science Congress.
November 17-24, 1996. New Delhi. P9015:p278.

Samadia DK \& Pareek OP. 1998. Genetic diversity in watermelon type "Mateera" (Citrullus lanatus) in hot arid environment. Abstract of paper In: XVIIIth International Congress of Genetics. August 10-15, 1998. Beijing, China. 8P64:p147.

Samadia DK \& Pareek OP. 2001. AHW-19 and AHW-65: New mateera varieties. Indian Horticulture, 46 (2): 8-9 \& 21.

Samadia DK and More TA. 2011. Thar Manak to quench thirst in desert. Indian Horticulture, 56 (5): 14-15.

Samadia DK, Nallathambi P, Vashishtha BB \& Dhandar DG. 2002. Quality improvement in drought hardy mateera (Citrullus lanatus) under hot arid conditions. Abstract of paper In: International Conference on Vegetables. November 10-14, 2002. Bangalore, India. II-86P:pp84-85.

Samadia DK, Pareek OP \& Vashishtha, BB. 2000. AHW-19 and AHW-65: Watermelon type mateera selections for the hot arid eco-system. Abstract of paper In: Third International Crop Science Congress-2000, August 17-22, 2000. Hamburg, Germany.

Samadia DK. 2003. Genetic resource management for sustainable horticultural development in arid regions of India. In: Sustainable Resource Management (eds. B.B.S. Kapoor and Ali Ahemad), Madhu Publications, Bikaner (India). pp163173.

Samadia DK. 2006. Mateera. In: Prospects and dimension for utilization of arid 
foods (eds. Goyal, M. and S.K. Sharma), Yash Publishing House, Bikaner. pp7983.

Samadia DK. 2007. Arid Vegetables. In: Underutilized and under exploited horticultural crops. Peter, K.V. (ed.), Vol. 2 New India publishing agency, New Delhi (India), pp153-174.

Samadia DK. 2007. Studies on genetic variability and scope of improvement in round melon under hot arid conditions. Indian Journal of Horticulture, 64 (1): 58-62.

Samadia DK. 2014. Mateera: Research and development in arid region (Hindi),
Technical bulletin - 45, ICAR-CIAH, Bikaner. 44p.

Samadia DK. 2015. Mateera - Thar Manak: Grow with innovative technological advancement. Technical Folder, CIAH, Bikaner, 6p.

Samadia DK. 2016. Horticulture based crop production site management approach (HBCPSMA) - an innovative concept for doubling farm income under dry-lands. Journal of Agriculture and Ecology, 1: $1-9$.

Samadia DK. 2018. Cultivating underutilized vegetables in arid region. Indian Horticulture, 63 (4): 34-39. 